\title{
On the Hypothetical State of Nature of Hobbes and Kant; Same Premises, Different Conclusions
}

\author{
Amer N. Shatara, PhD \\ Department of Philosophy, The University of Jordan, Jordan
}

doi: 10.19044/esj.2016.v12n23p209 URL:http://dx.doi.org/10.19044/esj.2016.v12n23p209

\begin{abstract}
Although there are stable and settled strains and classifications of social contract theorists, mainly contractualist - contractarianists, hypothetical - historical, and modern - contemporary, these classifications are not always specific and distinct. In fact, the same philosopher can be listed in more than one category, depending on different evaluations and perspectives. At times, the names of the thinkers on the list of any category can be very fluid. Moreover, some philosophers, because of the sharp distinction between them, are rarely mentioned together in one list or category, as is the case of Hobbes and Kant. In this paper, I will argue that Hobbes and Kant, with all their distinctions and differences, can be listed in the hypothetical agreement list, if we consider their "state of nature" as the starting point. From this perspective, I will argue that they exhibit less diversity than is usually acknowledged.
\end{abstract}

Keywords: State of nature, Hobbes, Kant, Social contract

A comparison between Hobbes and Kant, surely, has a limit that cannot be breached, because they are usually considered to be oriented in opposite directions and represent different political and philosophical trends: While Hobbes is considered to be a classical realist, Kant is usually regarded as a liberal advocate.

Nonetheless, Hobbes and Kant share many ideas regarding their social contract theory, which altogether, may reveal that the gap between them is narrower than has previously been considered. These ideas are concentrated around their concepts of the rationality of agents, hypothetical contract, property rights and the right to rebel. All of these concepts find their roots in the concept of the state of nature.

What I have concluded is that when analyzing the state of nature as presented by Hobbes and Kant, and further, when comparing them to each other, the similarity between them reveals a sharp consonance that reduces 
the apparent gap between them. Although their political and philosophical orientations and tendencies are different, their premises are very similar.

\section{The state of nature}

Few concepts in the history of political philosophy have been as controversial as the concept of the state of nature. One of the basic traditions that we can find in almost all of the contractarian thinkers, which indeed has been criticized by many ancient and contemporary thinkers, is the tendency to develop their views of government by putting forward specific conceptions of humans and society. In fact, the philosophical function behind the use of the state of nature is not something about which all can agree. It can have different philosophical functions, depending on the philosopher's view; it can be used to legitimatize some political or moral aspects, or it can be used to confirm some historical evidence regarding the essence of mankind, whether it has any real historical existence or is just for the sake of proving or explaining something, i.e. a hypothetical.

What is man's position before the existence of any law or authority? It is a position in which man was on his own necked- pure nature. "Here nature could mean wholly opposite conditions: the innocent man or the mere beast" (Williams, 1980, p. 76). Hobbes defended it as a "state of incessant mutual exploitation", more famously known as a "state of war" (Hobbes, 1651, p. 70). Locke considered it as a "state of freedom and equality", while Rousseau saw man, in the state of nature, as born free and equal, although everywhere he is in chains. Kant viewed the natural state of man not as peaceful co-existence, but as being at war - not always open hostilities, but at least an unceasing threat of war.

The state of nature is the condition under which individuals lived prior to the existence of society. It is a hypothetical claim that - according to some contract theories - helps to "illustrate a direction for suggesting what are the ends of the state and then to eliminate the problems illustrated in the state of nature” (Hurley, 2001, p. 1). But even as a hypothetical claim, it has played a great role in shaping the most efficient points regarding each social contract theory. I think that the idea of the state of nature itself is worth exploring. It is like what Claude Levi-Strauss called a "floating signifier" that denotes signifiers without referents or a word that really does not point to any object.

Ironically, the essential function of the state of nature, as a concept, was to justify authority and to confirm the rights of individuals as stated by the classic theory of social contract; such state of nature was hypothetical, as it never really existed (at least this is the claim of some of the classic Social contract theories). However, as Charles Mills expressed in his book, The Racial Contract, it stimulates our imagination - intentionally or not - to 
think about societies living in primitive or "savage" situations, which may lead to a hierarchy between human beings, or even worse, to racism.

In fact, when we look at world history and previous political thought, we can find the idea of such an imaginary state of nature, similar to the idea constructed in the beginning of the modern era in Western political thought. For example, we find the fabulous story of Hayy ibn Yaqzan of Ibn Tufayl (1105-1185), a Muslim philosopher who lived in Andalusia (Al- Andalus), which has some similarities to Daniel Defoe's story, Robinson Crusoe. Hayy ibn Yaqzan is the story of a man called Hayy: "[H]e is man imagined in a pre- and non-political setting,... A story which presents a 'state of nature' scenario, guiding the reader through a philosophical fantasy of what man in isolation is, the knowledge (or super situations) he might acquire ...." (Carlson \& Fox, 2014, p. 146). The common concept between the two stories (the Western and the Eastern) is their imaginary situation of the state of nature, although there are more details in the case of Ibn Tufayl, which we do not find in the Western version of the social contract. Most importantly, Ibn Tufayl's state of nature does not contain fear or danger from others; rather it is "initiated by the recognition of change in others, particularly the notions of generation and growth, and a deep discomfort that accompanies the sense of being left or lagging behind” (Carlson \& Fox, 2014, p. 151).

\section{Hobbes' state of nature}

Hobbes viewed the state of nature as a condition of passions and desires, which, in turn, creates conflict and distrust among individuals where no rule or justice exists: "A war of all against all”. Hobbes derived this notion of the state of war from his views of human nature. Because, in the state of nature, there is no government, and everyone enjoys equal status, every individual has a right to everything; that is, there are no constraints on an individual's behavior. Anyone may, at any time, use force, and all must constantly be ready to counter such force with force. Hence, driven by acquisitiveness, having no moral restraints, and motivated to compete for scarce goods, individuals are apt to "invade” one another for gain. Being suspicious of one another and driven by fear, they are also likely to engage in preemptive actions and invade one another to ensure their own safety. Finally, individuals are also driven by pride and a desire for glory. Whether for gain, safety, or reputation, power-seeking individuals will thus "endeavor to destroy or subdue one another” (Hobbes, 1651, XIII 3). In such uncertain conditions, in which everyone is a potential aggressor, making war on others is a more advantageous strategy than peaceable behavior, and one needs to learn that domination over others is necessary for one's own continued survival. 
As Hobbes put it: “..., where every man is Enemy to every man..., wherein men live without other security, than what their own strength and their own invention shall finish them withal. In such condition, there is no place for Industry; because the fruit is uncertain: and consequently no culture of the Earth; no navigation, nor use of the commodities that may impose by see; no commodious building; no Instruments of moving, and removing, no account of time; no Arts; no Letters; no Society; and which is worse of all, continual fear, and danger of violent death; and the life of man, solitary, poor, nasty, brutish, and short” (Hobbes, 1651, p. 70).

Thus, the Hobbesian state of nature is a situation in which there are no rules, no government and no authority. It is the kingdom of "No", and obviously, of "fear". Hobbes aimed to force us to use the power of our imaginations to determine what life would be like in such a situation. In Leviathan, Hobbes' answer was clear: It would be "solitary, poor, nasty, brutish and short” (Hobbes, 1651, p. 56). It would be a life outside of society or perhaps preceding its establishment.

Hobbes' comprehension of the concept of the state of nature was not derived from historical readings or from any scientific analysis of nature; rather, it was a hypothetical theory and stemmed from his conclusions about human nature. But, did Hobbes need the idea of the state of nature - in general - in order to support the sovereign's absolute authority? Hobbes argued that it was not desirable, but was a necessary structure to protect man in civil society. In Leviathan, he mentioned: "[F]or all men are by nature provided of notable multiplying glasses, (that is their passions and self-love), through which, every little payment appeareth a great grievance; but are destitute of those prospective glasses, (namely Moral and Civil Science), to see a fare off the miseries that hang over them, and cannot without such payments be avoided” (Hobbes, 1651, p. 102).

The last statement can be understood as Christine Korsgaard suggested, i.e., "that theoretical justifications can be used to illuminate aspects of practical justifications" (Hurley, 2001, p. 16). Consequently, Hobbes' argument was that because the state of nature is a war of all against all, it necessarily requires an unquestionable and absolute sovereign: “... they that have already Instituted a common -wealth, being thereby bound by Covenant, to own the action, and Judgments of one, cannot lawfully make a new Covenant, amongst themselves, to be obedient to any other, in anything whatsoever, without his permission ...” (Hobbes, 1651, p. 96).

Hobbes' social contract theory is, in a sense, a reflection of his experience of the civil wars and political upheaval in his time. They inevitably led him to think about the brutal reality of instinctive human behavior, and thus, played a significant role in shaping his pessimistic view about human nature. More importantly, these events "instilled in Hobbes a 
strong conviction for an absolute monarchy, believing that ultimately the only capable form of social governance was a sovereign with unrestricted ruling power" (Mouritz, 2010, p. 124). Accordingly, Hobbes' aim was to undergird a powerful sovereign.

The hypothetical theory of social contract is an imaginary premise and a mental construct regarding the past of human society, but in fact, it has roots in the present of society, i.e., it is used to illuminate aspects of practical justifications. We cannot detach any philosophy from its time and context; when Hobbes defended a pessimistic view about man in the state of nature and transferred full power to the ruler in order to control this complex and selfish behavior, he was considering his own society and its problems.

To the contrary, when the context is different, we can find great adjustment in the Hobbesian imaginary state of nature. Locke, for example, adopted a very different state of nature and suggested a different contract theory as well. One of the main reasons that we can mention for this change, among others, is Locke's different historical background. His intention was mainly to prevent an absolute monarchy, rather than to ensure a sovereign ruler, as in Hobbes' situation. That is why one of the most important notions in Hobbes' contract theory was the "fear of death" and one's "selfpreservation". These notions are fully dependent on man's situation in the state of nature. This is because our state of nature is common, and because there is "no way for any man to secure himself, except by force, or wiles to master the persons of all men he can, so long, till he see no other power great enough to endanger him” (Hobbes, 1651, p. 184). Hobbes described this situation as a state of war, all against all, and "every man against every man ..., Where there is no common power, there is no law" (Hobbes, p. 186). As a result, Hobbes concluded that there was only one solution for man to escape this bad situation: "[A]ll individuals must enter to covenant with every other person, agreeing not to harm one another" (Gauthier, 1988, p. 134). Obviously, in answer to the question of "why should we live under the rule of law", Hobbes' conclusion stemmed from his view of the state of nature. Further, he expected us to come to the same conclusion. Thus, rationality will play an important role in concluding that we should agree to seek peace. Thus, "the idea of an original contract derives consent from reason, which itself is given by our humanity, we consent because we are rational creatures who could only consent to political legitimacy if we understand what follows necessarily from the general idea of a state" (Weber, 2010, p. 6).

The above argument can be shown as a reason to consider Hobbes' contract theory as a hypothetical one, because it hypostatizes the past in order to justify the present. It imagines a past that can help to solve the problems of his society. Moreover, Hobbes argued that although our 
"reason" can, through rational thinking, understand that the state of nature is a problem for everyone, this same reason cannot maintain peace by itself, unless a powerful sovereign takes control. It seems as though, for Hobbes, our rationality is an agent for the sovereign; the best it can do is to deliver man consensually to a powerful sovereign. For Hobbes, the problem starts when individuals come together and interact with each other; "when man interacts with man, he does so as an animal, specifically as a wolf, such that after the state of nature, the sovereign remains a wolf while his subjects become a different animal, namely cattle or sheep” (Carlson \& Fox, 2014, p. 149).

Thus, Hobbes' state of nature can be considered hypothetical, and thus, it is much closer to Kant's view than to those of Rousseau and Locke. Although Kant was highly influenced by Rousseau, we can find that Kant displayed more similarity and resemblance to Hobbes than to Rousseau or Locke. As a hypothetical theorist, Hobbes did not believe the state of nature was something that happened in actual time. We can deduce this idea in many parts of his book, Leviathan, in which he stated: "[I]t may peradventure be thought, there was never such a time nor condition of war as this; and I believe it was never generally so...” (Hobbes, 1651, p. 71), and "[b]ut though there had never been any time, wherein particular men were in a condition of war one against another; ...” (Hobbes,1651, p. 71).

Moreover, while Hobbes described the state of nature, he was clear and distinct that in such a state, there is no notion of justice and morality: "To this war of every man against every man, this also is consequent; that nothing can be unjust. The notion of right and wrong, justice and injustice have there no place...” (Hobbes, 1651, p. 71). However, when he discussed the original people of America, he mentioned that they had some morality: "...The Savages of America are not without some good moral sentences..." (Hobbes, 1651, p. 233). This clearly indicates that Hobbes' state of nature does not resemble an actual time or place, but rather a hypothetical idea, just as Kant's does.

\section{Kant's state of nature}

The concept of the state of nature in Kant's philosophy is not as apparent as in Hobbes' philosophy or those of the other social contractors, such as Locke and Rousseau. In other words, we can say that human nature is far more complicated in Kant's philosophy than in those of Hobbes, Locke and Rousseau.

Hannah Arendt, in her book, Lectures on Kant's Political Philosophy, gives us an important clue to understand Kant's philosophy in a proper way. She said: “....the distinctions among these three perspectives are a necessary precondition for an understanding of Kant. Whenever he speaks of man, one 
must know whether he is speaking of human species; or of the moral being, the rational creature that may also exist in other parts of the universe; or of man as actual inhabitants of the earth” (Arendt, 1992, p. 26). Arendt argued that this means that from Kant's perspective, "man as a moral being" is an end in himself, while to the contrary, man as a human species is subject to endless progress: a hope for a better future for following generations. Kant's argument continued: "on the common saying: this May be true in Theory, but it does not apply in Practice”, that, "... first in morality in general, to the regard to the welfare of each individual man, secondly in politics, with regard to the welfare of states, and thirdly in the cosmopolitical sphere, with regard to the welfare of the human race as a whole...”" (Reiss, 1970, p. 63).

Hence, from Kant's perspective, the difference between politics and morals relies on the dependence of politics on 'public conduct'; it is the conflict between the individual and society. However, political duties are not perfect duties toward oneself, "but only what Kant calls perfect duties toward others” (Reiss, 1970, p. 20). As a solution for such conflict, Kant considered morality as being fit to be seen. A bad man, for Kant, is one who makes exceptions for himself. To be evil, therefore, is characterized by "withdrawal from the public realm” (Arendt, 1992, p. 49). This implies an alliance and a relationship between morals and politics, as it suggests that individuals' actions should be considered in relation to other men in society.

For Kant, the existence of law was essential in order to resolve public conflicts of interest. In his book, Toward perpetual peace, especially in the second section, the definitive articles for perpetual peace among states are quite clear. "The natural state of man is not peaceful co-existence but war not always open hostilities, but at least an unceasing threat of war” (Kant, 1651, p. 72). Hobbes also argued that an alliance against any attacks should be adequate and sufficient, "so that if we must have war, it will not be a war against all men nor without aid” (Hobbes, 1987, p. 30). Hobbes believed that both cooperation and joint action will be the basis for establishing a commonwealth: "[W]e are driven by mutual fear to believe that we must emerge from such a state and seek allies” (Hobbes, 1987, p. 30).

For Kant, the importance of the civil state relied - among other reasons- on the preservation of the law: "Real security against outbreaks of war is something that has to be pledged to each person by his neighbor (a thing that can occur only in civil state); without that pledge, each person may treat his neighbor as an enemy” (Kant, 1651, p. 72). Eventually, Hobbes also agreed with Kant about the ultimate role of the state in preserving the law. For both Hobbes and Kant, there was no chance to construct a state while remaining in the state of nature. The only hope for establishing public peace was the departure from that natural state toward the state. For both of them, the state of nature was a state of war. We ordinarily assume that no one is 
permitted to act in a hostile way toward someone who has not actively harmed him. That is quite correct if both men are under civil law, because by entering into a civil state, they have given each other the required security through the government, which has power over both of them (Kant, 1651, p. 73). Like Hobbes, Kant very clearly emphasized the very dangerous situation of the state of nature for individuals: "A man ... in the state of nature deprives me of this security; even if he doesn't do anything to me - by the mere fact that he isn't subject to any law and is therefore a constant threat to me” (Kant, 1651, p. 73). For Hobbes, as for Kant, the state's existence is essential for the maintenance and propagation of civility. Although they developed different visions of the social contract, they shared approximately the same concept of the state of nature. "For if even one pair of these items two men, two nation states, or one man and one nation state - were in a position to affect one another and yet were in the state of nature, war would necessarily follow ...” (Kant, 1651, p. 73).

Kant again used the Hobbesian idea of the state of nature to resolve the problems and conflicts that occurred between states, rather than among individuals. Because of the absence of the law, Kant argued, both individuals and states lack any kind of security in their state of nature. As Kant put it: "Nowhere does human nature appear less admirable than in the relationship which exists between people” (Reiss, 1970, p. 91). The Kantian solution for the conflict between states depends on the constitution of a strong federation between states. "Although it has been maintained that Hobbes pays little attention to the relationship between the domestic and external order, Sharon argues, we can find a connection between the well-ordered state and peace in Hobbes that has an interesting similarity to Kant's view of the relation between the achievement of well-ordered states and peace” (Gold, 2012, p. 12). Kant maintained that reason requires the states to depart from the state of nature, and both Kant and Hobbes shared the same idea about the formation of the state as a "moment of historical progression that is morally significant and not to be dissolved in the favor of a world state” (Gold, 2012, p. 12).

Surprisingly, Kant, similar to Hobbes, rejected the right to rebel. It is quite strange that Kant, despite all of his efforts to emphasize the freedom of human beings and despite the natural laws that ensure the freedom and equality of all individuals in the state of nature (in the case of Hobbes and Locke), these views did not allow him to recognize the right of people to rebel. Kant believed that a good man can be a good citizen only in a good state. For Kant, the "problem was how to force man to be a good citizen, even if (he is) not morally a good person” (Arendt, 1992, p. 17). Moreover, he emphasized that "a good constitution is not to be expected from morality, 
but controversy, a good moral condition of a people is to be expected under a good constitution” (Arendt, 1992, p. 17).

Locke, whose views are, in general, supposed to be much closer to Kantian philosophy, acknowledged the right of people to rebel if the sovereign violated the natural laws or misused his power, and thus, it is quite strange that Kant rejected this fundamental right. It seems that Kant, as Reiss noted, was "a man of conservative disposition who refused to countenance revolution in politics as a legitimate principle of action” (Reiss, 1970, p. 3). Kant's disapproval of this kind of behavior can be interpreted as similar to Hobbes' philosophy regarding the state of nature that may govern individuals' behavior in the absence of or demolition of the authoritative power that controls all of them. Kant argued that "all resistance against the supreme legislative power, all incitement of the subjects to violent expression of discontent, all defiance which breaks out into rebellion, is the greatest and most punishable crime in commonwealth, for it destroys its very foundations" (Otteson, 2009, p. 396).

Kant did not even permit the people to revolt against a tyrannical state, because, as for Hobbes, individuals "owe an absolute allegiance to the particular state to which they belong” (Otteson, 2009, p. 397). For both Kant and Hobbes, the sovereign is not a member of the commonwealth, but rather its creator, and consequently, is above its laws.

Moreover, although Kant condemned war (similar to Hobbes), it could nonetheless be seen as good for individuals, because it may bring about progress toward peace for following generations. In another words, for Kant, war, in general, may "have an educative effect which carries awareness of moral principle and puts us back on the right path” (Gold, 2012, p. 15). Kant argued that "universal violence and the distress it produced must eventually make all people decide to submit to the coercion of reason which reason itself prescribes (i.e., the coercion of public law) and to enter a civil constitution” (Reiss, 1970, p. 90). Moreover, Kant contended that the state can also learn, from the individuals who suffer and enter into a cosmopolitan constitution, that "the distress produced by the constant wars in which the states try to subjugate or engulf each other must finally lead them, even against their will, to enter into a cosmopolitan constitution” (Reiss, 1970, p. 90). It seems that Kant took the ideas of Hobbes and asserted that they were valid between states, not just between individuals in the state of nature.

Kant considered the state of nature not just a state of anarchy and violence, but also as a state in which there were no property rights. The Kantian connection between the absence of morality and property rights in the state of nature is interesting. Locke had a different approach towards property rights in that he recognized the existence of property rights in land, animals and some products of nature only by reference to the laws of nature 
before the existence of the state. Private property rights, in Locke's contract, played an important role in differentiating Locke's liberal tendencies from Hobbesian absolutism. While Kantian thought - in general- seems to contain a great deal of correspondence to Locke's and Rousseau's political philosophies, we find that it rather has more propinquity with Hobbes' philosophy, especially in a comparison of their views about the state of nature. For Kant, as for Hobbes, "the state of nature resembles anarchy. Kant therefore knows no moral standards that would apply to the individual in the state of nature, since he negates any claims of property therein" (Royce, 2010, p. 51). For Kant, private property rights emerged after the formation of the state, not before it. For Kant, as for Hobbes, one of the main duties of the state is to protect the property rights of the individuals within the contract. For both of them, the essence of the existence of the state relies on the preservation and protection of individual rights, such as the private property of each individual.

In De Cive, Hobbes wrote about the important role of reason for individuals to escape the state of nature: "[A]ll men easily recognize that this state - of nature -, is evil when they are in it; and consequently that peace is good. Thus though they cannot agree on a present good, they do agree on a future good. And that is the work of reason ... reason teaches that peace is good; it follows by the same reason that all necessary means to peace are good, and hence that modesty, fairness, good faith, kindness, and mercy are good manners or habits, i.e. virtues. Hence by the fact that law teaches the means to peace, it teaches good manners or virtues. And therefore called moral” (Hobbes, 1987, p. 55).

The equality between individuals in the state of nature, which Hobbes assumed, would be a serious obstacle to the achievement of peace; in the absence of authority, war between equal individuals will become inescapable. As a result, "the idea of an original contract derives consent from reason, which itself is given by our humanity. We consent because we are rational creatures who could only consent to political legitimacy if we understand what follows necessarily from the general idea of a state" (Weber, 2010, p. 6). Kant also maintained the same Hobbesian conclusion, asserting that "reason" will drive individuals to depart the state of nature. Kant believed that "history is a progress toward rationality" (Reiss, 1970, p. 36); consequently, civil society is a product of reason and rationality. Kant argued that universal violence and the distress it produces must eventually cause people decide to submit to the coercion that reason itself prescribes (i.e., the coercion of public law) and to enter into a civil constitution. Another important feature of Hobbes' and Kant's state of nature was connected directly with passions, i.e., the irrationality of passions, which they considered as the source of all evil and conflict among individuals in the 
state of nature. It is very surprising to read what Kant wrote in the Sixth Proposition of his Idea for a Universal History From A Cosmopolitan Perspective: "The human being is an animal which, when he lives among others of his own species, needs a master"; Kant continued to justify this conclusion, stating: "This is so because he will certainly abuse his freedom with regard to others of his own kind. And even though he, as a rational creature desires a law that sets limits on the freedom of all his selfish animal inclinations will lead him to treat himself as an exception whatever he can, For this reason he needs a master" (Wood, 2001, p. 124). The comparison between Hobbes and Kant regarding human nature and its consequence, the state of nature, is inescapable. For both of them, human beings' "rationality" cannot provide much help in bringing about peace. Rationality can lead to the conclusion that human beings should find a sovereign among themselves to enforce the law. For Hobbes, as for Kant, in the state of nature, every individual has a right to everything; that is, there are no constraints on an individual's behavior. Anyone may, at any time, use force, and all must constantly be ready to counter such force with force. We, as individuals with bad natures, will not find peace and stability unless we give our consent to the political authority as the only rational way.

\section{Conclusion}

The state of nature is one of the most important concepts in any classic contract theory. It attempts to answer the big political question "why be governed?", to justify authority, and to identify the relation between the individual and that authority. The state of nature is important within the whole concept of contract theory, in the logic that leads man to obey, and in the rational steps that man can take to achieve stability and peace.

I think that any theory has a final target to satisfy. Thus, social contract theorists have a final target to satisfy regarding the type of authority they want to establish. I have argued that even if Hobbes and Kant are referring to different eras, and most importantly, to different political tendencies, they nevertheless have many ideas in common.

I think it is fascinating to see the similarities in the state of nature as set forth by Hobbes and Kant. What makes this situation interesting is that the real differences arise in their vision of man and life in general. It is as if they start with the same premises, but ultimately end up with different conclusions. The state of nature for both of them, as their starting premises for building a social contract, are very similar, while their conclusions and answers to the main political questions, such as "why be governed", are totally different. 


\section{References:}

Arendt, H. (1992). Lectures on Kant's political philosophy. Chicago: The University of Chicago Press.

Carlson, D. J., \& Fox, R. A. (2014). The state of nature in comparative political thoughts. United Kingdom: Lexington Books.

Gauthier, D. (1988). Hobbes's social contract; perspectives on Thomas Hobbes. Oxford University Press.

Gold, A. S. (2012). Philosophers of peace: Hobbes and Kant on international order. Hobbes Studies Journal, 25(2012), 6-20.

Harris, E. (1992). From social contract to hypothetical agreement. Columbia Law Review, 92(3), 651-683.

Hobbes, T. (1651). Leviathan the matter, forme, \& power of a commonwealth, ecclesiastical and civill. London: Green Dragon.

Hobbes, T. (1987). De cive. (Howard Warrender, ed.). New York: Oxford University Press.

Hurley, P. (2001). A Kantian rationale for desire-based justification. Philosopher's Imprint, 1(2).

Mills, C. W. (1997). The racial contract. USA: Cornell University Press.

Mouritz, T. (2010). Comparing the social contract of Hobbes and Locke. The Western Australian Jurist, 1.

Otteson, J. R. (2009). Kantian individualism and political libertarianism. The Independent Review, 13(3), 389-409.

Reiss, H. (1970). Kant's political writings. Cambridge University Press. U.S.A.

Royce, M. (2010). Philosophical perspectives of the social contract theory: Hobbes, Kant and Buchanan revisited. A comparison of historical thought surrounding the philosophical consequences of the social contract and modern public choice theory. Postmodern Openings, 4, 45-66.

Weber, E. T. (2010). Social contract theory, old and new. The Review Journal of Political Philosophy, 7(2), 1-23.

Wood, A. W. (2001). Basic writings of Kant. New York: The Modern Library.

Williams, R. (1980). Ideas of nature, in problems in materialism and culture. London: Verso. 